\title{
Perspectives of US Youth During Initial Month of the COVID-19 Pandemic
}

\author{
Eric Waselewski, $M D^{1}$ \\ Marika Waselewski, MPH ${ }^{2}$ \\ Chloe Harper ${ }^{3}$ \\ Sarab Dickey \\ Sue Anne Bell, PbD, FNP-BC $C^{4,5}$ \\ Tammy Chang, MD, MPH, $M S^{2,5}$ \\ 'University of Michigan Department \\ of Internal Medicine, Ann Arbor, Michigan \\ ${ }^{2}$ University of Michigan Department \\ of Family Medicine, Ann Arbor, Michigan \\ ${ }^{3}$ Skyline High School, Ann Arbor, Michigan \\ ${ }^{4}$ University of Michigan School of Nursing, \\ Ann Arbor, Michigan \\ ${ }^{5}$ University of Michigan Institute \\ for Healthcare Policy and Innovation, \\ Ann Arbor, Michigan
}

Conflicts of interest: authors report none.

\section{CORRESPONDING AUTHOR}

Marika Waselewski

Department of Family Medicine

University of Michigan

2800 Plymouth Road

Building 14 G128

Ann Arbor, MI 48109

marikag@med.umich.edu

\begin{abstract}
PURPOSE Asymptomatic youth in the United States acting as "silent spreaders" during the coronavirus disease 2019 (COVID-19) pandemic are an ongoing public health concern, particularly given their depiction as unengaged with recommendations. Our goal was to understand the knowledge, beliefs, and experiences of US youth at the onset of the COVID-19 pandemic.
\end{abstract}

METHODS We posed 2 open-ended surveys to the national MyVoice text message cohort of youth, aged 14-24 years. On March 6, 2020, 4 questions were asked regarding knowledge and experiences during the COVID-19 pandemic with 3 questions repeated on March 20, 2020. Qualitative responses were coded using thematic analysis and summarized with descriptive statistics.

RESULTS Of 1,174 youth, 1,087 responded to at least 1 question (response rate of $88 \%$ ). The average age of respondents was 19 (SD 2.8) years with $52 \%$ female and 56\% non-Hispanic White respondents. On March 6, 2020, most (70\%) respondents reported knowing about COVID-19 and primarily cited the news (46\%) as their source of information. Nearly all (95\%) respondents reported impact by March 20, 2020, and respondents expressing worry increased from $25 \%$ to $51 \%$. In both surveys, worried youth primarily cited concern for others (26\% and $34 \%$ ). Regarding preparation, respondents primarily reported doing nothing (36\%) on March 6, 2020, and practicing social distancing (50\%) on March 20, 2020.

CONCLUSIONS Many youths in our sample are engaged with the COVID-19 pandemic and most are feeling knowledgeable, are concerned about its impacts on others, and are practicing social distancing. Sustained public health efforts should focus on maintaining youth engagement with accurate public information and youth-centered messaging promoting prevention measures to protect the health and well-being of youth and their friends and family.

Ann Fam Med 2021;19:141-147. https://doi.org/10.1370/afm.2642.

First appeared as an Annals "Online First" article on January 24, 2021.

\section{INTRODUCTION}

A dolescents and young adults have been shown to be at lower risk for coronavirus disease 2019 (COVD-19) morbidity and mortality with asymptomatic and less serious cases skewed toward younger individuals. ${ }^{1,2}$ As a result, pandemic impacts on this age group are largely related to interruptions in education, work, and social interactions..$^{3.5}$ Evidence suggests, however, asymptomatic youth may contribute to pandemic progression as "silent spreaders," that is, individuals who transmit the disease without exhibiting symptoms. ${ }^{1,2,6,7}$ Concerns regarding the health and well-being of youth as well as their potential role as silent spreaders make this group, nearly 13\% of the US population (aged 15-24 years), important in understanding the epidemiology of this pandemic and guiding ongoing public health efforts. ${ }^{8}$

Youth are also commonly depicted as being unengaged in current events, unenthusiastic about political engagement, and generally disconnected. ${ }^{9-13}$ Despite increased visibility of youth in advocacy, particularly focused on gun violence in schools, climate change, and social justice, 
the prevailing depiction of youth continues to be overwhelmingly, and sometimes inaccurately, apathetic and negative. ${ }^{14-19}$ Psychologists and media have further labeled young adults as reward driven, lacking empathy, and increasingly self-absorbed. ${ }^{20-26}$ However, many of these characteristics are part of normative neuro-biologic development and play important roles in learning, relationship development, and risk-taking behaviors essential to adolescent growth. ${ }^{21,27}$

During the COVID-19 pandemic, these views of adolescents and young adults have gained additional traction with reports of these age groups ignoring social distancing guidelines to pack bars, visit beaches, and convene in large groups with others. ${ }^{28-30}$ Insight on youth behaviors and their perceptions are limited, however, as is scientific knowledge of COVID-19, resulting in a need for continued efforts to understand the many facets of the pandemic. Our study aims to assess the knowledge, beliefs, and experiences of adolescents and young adults to discern their understanding, feelings, and behaviors during the COVID-19 pandemic and how they evolved as the pandemic progressed.

\section{METHODS}

Our study used the MyVoice cohort, a national longitudinal mixed-methods text-message poll of youth, that seeks to understand youth opinion on salient health and policy issues. ${ }^{31}$ The MyVoice cohort is a diverse sample of youth, aged 14-24 years, across the United States, recruited via social media and community events with the goal of meeting national benchmarks from weighted samples of the American Community Survey. Individuals are eligible to participate with the following criteria: aged 14-24 years, English literacy, and access to a phone with text-messaging capabilities. This study was approved by the University of Michigan Institutional Review Board with a waiver of parental consent for minors.

Two open-ended surveys were sent to MyVoice participants in March 2020. The first, sent on March 6, 2020, was composed of 4 questions on knowledge, beliefs, and behaviors surrounding the COVID-19 pandemic. The second survey, sent on March 20, 2020, had 3 different questions, to capture their evolving experiences. Respondents were given 1 week to respond to each set of questions. Survey questions were iteratively developed by a team of youth, researchers, and methodologic experts to ensure clarity and appropriateness.

\section{March 6, 2020 Survey Questions}

1. What do you know about coronavirus or COVID19 ? Where did you hear that?
2. How has the current coronavirus situation impacted you, if at all?

3. Are you worried about coronavirus? Why or why not? 4. Are you doing anything to prepare for coronavirus? If so, what?

\section{March 20, 2020 Survey Questions}

1 . How has coronavirus affected your life?

2. Are you worried about coronavirus? Why or why not? 3 . Are you doing anything to prepare for coronavirus? If so, what?

After survey results were obtained, thematic review of the data was performed by 2 authors (E.W., M.W.) and a codebook developed. All responses were then coded independently by different pairs of authors (E.W., M.W., S.A.B., S.D., C.H.) with a third author (from the same group) reviewing for discrepancies and reconciling differences. Summary statistics for demographics and code frequencies were completed with SAS version 9.4 (SAS Institute Inc).

\section{RESULTS}

A total of 1,087 (88\%) out of 1,174 MyVoice members participated in either the March 6, 2020 (90\% response) or March 20, 2020 (87\% response) survey. The average age of respondents was 18.9 (SD 2.8) years with $52 \%$ of respondents identifying as female, $56 \%$ as non-Hispanic White, and 36\% with an education less than high school. Table 1 shows complete demographics for all respondents. After thematic analysis, 3 key themes emerged: (1) youth reported feeling knowledgeable about COVID-19 with the news as their primary source of information $;$ (2) youth felt increasingly worried, mostly for their family or friends ${ }_{i}(3)$ many youth shifted from doing nothing to prepare for COVID-19 to social distancing within the study period.

Most respondents to the survey sent March 6, 2020, reported knowledge regarding the COVID-19 pandemic $(70 \%$; Table 2$)$. Of these individuals, many reported that "It's a viral outbreak...that consists of fever and shortness of breath or cough" (56\%), "It's spread from surfaces, is highly contagious...." (50\%), "It's a coronavirus from Wuhan Province in China" $(43 \%)$, and that it "... is much more dangerous for elderly and chronically ill" (23\%). Some respondents noted additional details about COVID-19 including disease prevalence ("100 in the United States with 100,000 in the world") and fatality rates ("it has a death rate of about $2 \% "$ ). Some expressed beliefs, however, that were not supported by evidence ( $8 \%$ ) such as "I know it is a stronger strain of the common flu," "... said to be man-made," or "...it's only lethal to people with underlying conditions." 


\begin{tabular}{|lc|}
\hline \multicolumn{2}{|c|}{ Table 1. Demographic Characteristics of } \\
Respondents on Either March 6, 2020 or March \\
20, 2020 (N = 1,087) & \\
\hline Characteristic & All Respondents \\
\hline Age, mean (SD), y & $18.9(2.8)$ \\
Sex, No. (\%) & $429(39.5)$ \\
Male & $561(51.6)$ \\
Female & $97(8.9)$ \\
Other sex & \\
Race/Ethnicity, No. (\%) & $605(55.8)$ \\
Non-Hispanic White & $99(9.1)$ \\
Non-Hispanic Black & $143(13.2)$ \\
Hispanic & $238(21.9)$ \\
Non-Hispanic other & \\
Education level, No. (\%) & $392(36.1)$ \\
Less than high school & \\
High school grad & $172(15.8)$ \\
Some college or tech school & $311(28.6)$ \\
Associate's or tech grad & $37(3.4)$ \\
Bachelor's degree or higher & $175(16.1)$ \\
Region, No. (\%) & \\
Midwest & $393(36.2)$ \\
Northeast & $169(15.5)$ \\
South & $300(27.6)$ \\
West & $225(20.7)$ \\
HS free or reduced lunch, No. (\%) & \\
No & \\
\hline HS = high school; SD = standard deviation & \\
a Includes participants still in high school. & \\
\hline
\end{tabular}

Information known by respondents was primarily cited as coming from news sources (46\%) such as "CNN, ABC, NYT, FOX" or "from the radio news, NPR driving home." Other respondents noted learning their information "on YouTube," "from an account on Instagram," "from Twitter or Tiktok first," or other social media sites (17\%). Friends and family (12\%), government or academic sources (9\%), and schools (8\%) were also noted as sources of information.

On the week of March 6, 2020, most respondents (62\%) reported being impacted by the pandemic, which increased substantially to nearly all participants (95\%) being affected by the week of March 20, 2020. The primary types of impact also changed between surveys (Table 3 ). Initially, $28 \%$ of respondents noted doing "more handwashing" and being "... a little conscious about the spread of disease and how to remain healthy." At follow-up on March 20, 2020, most respondents cited logistical changes like "no job, no school" (64\%), "by keeping me inside" $(41 \%)$, or "everything I have to look forward to is cancelled" (12\%).
Participants' level of worry was also assessed in both surveys; on March 6, 2020, over one-half (51\%) expressed they were not worried. The remaining youth were split between somewhat worried (24\%) and worried (25\%). By the week of March 20, 2020, only onequarter $(24 \%)$ of participants indicated they were not worried and over one-half (51\%) felt worry.

Of individuals who were worried or somewhat worried, the most common reason, at both survey time points, was fear for others (26\% on March 6, 2020; $34 \%$ on March 20, 2020). Respondents noted being concerned "not for myself but for others" in general, as well as for specific individuals like "...my elderly loved ones" and "...my little one." A number (22\%, 21\%) also explicitly noted concern for susceptible populations, "...people who are immunocompromised." Other reported reasons for worry included concern about spreading the virus $(21 \%, 19 \%)$, the deadly or dangerous nature of COVID-19 (11\%, 15\%), fear for their personal health $(14 \%, 12 \%)$, and apprehension about poor management of COVID-19 "because the government doesn't seem to be handling it well" or "people aren't taking it as seriously as they should" (9\%, 12\%).

For participants who reported limited or no worry, the most commonly reported reason was because they were "...young and healthy" (28\% on March 6, 18\% on March 20). Others noted that engaging in prevention practices kept them from worrying $(13 \%, 15 \%)$ like being "...careful about washing my hands" and "... because I don't leave the house." Belief of COVID-19 as a mild disease or "...just a slightly more serious flu" was also reported, though less commonly as the pandemic progressed $(24 \%, 9 \%)$.

Early in the COVID-19 pandemic (March 6, 2020), respondents most commonly reported doing nothing to prepare (36\%), "washing [their] hands more" (30\%), "stocking up on food and sanitizer" (18\%), or "washing hands like normal" (17\%). At the follow-up on March 20, 2020, priorities had shifted. One-half of the respondents $(50 \%)$ reported "...trying to practice social distancing" and 39\% were buying "...enough groceries for us not to go out for 2 weeks." Increased or normal handwashing measures $(18 \%, 7 \%)$ were less common at these points, and only $15 \%$ reported no preparation measures being taken.

\section{DISCUSSION}

In this national longitudinal text message poll, a majority of the adolescent and young adult respondents felt they had specific knowledge of COVID-19. By March 20, 2020, nearly all participants reported being impacted, largely from school and work closures, and self-isolation. As the pandemic progressed, more 
Table 2. Youth Knowledge of COVID-19 and Sources of Information on March 6, 2020 ( $N=1,043)$

\begin{tabular}{|c|c|c|}
\hline Question, Theme ${ }^{a}$ & No. (\%) & Example Quote \\
\hline \multicolumn{3}{|c|}{ What do you know about coronavirus or COVID-19? Where did you hear that? } \\
\hline \multicolumn{3}{|c|}{ Types of information known } \\
\hline COVID-19 knowledge & $732(70.2)$ & \\
\hline \multirow[t]{2}{*}{ Disease characteristics } & $407(55.6)$ & "It has about a $2 \%$ fatality rate thus far...." \\
\hline & & $\begin{array}{l}\text { "It's a virus. Its symptoms are fever, cough, and } \\
\text { chest issues." }\end{array}$ \\
\hline \multirow[t]{2}{*}{ Contagiousness } & $365(49.9)$ & "...it's spreading rapidly..." \\
\hline & & $\begin{array}{l}\text { "... it is very contagious and spread through } \\
\text { droplets in the air." }\end{array}$ \\
\hline Origin or disease location & $316(43.2)$ & "It is in the United States and originated in China." \\
\hline \multirow[t]{2}{*}{ Susceptibility characteristics } & $166(22.7)$ & $\begin{array}{l}\text { "it mostly seems to kill the elderly or those with } \\
\text { pre-existing conditions." }\end{array}$ \\
\hline & & "I know fatality is low for my age." \\
\hline No COVID-19 knowledge & $44(4.2)$ & "I don't know anything." \\
\hline \multicolumn{3}{|l|}{ Perception of COVID-19 } \\
\hline Severe or deadly & $222(21.3)$ & "I know that people are dying...." \\
\hline Not severe & $134(12.8)$ & $\begin{array}{l}\text { "The infection rates are low, and fatality rates are } \\
\text { even lower." }\end{array}$ \\
\hline \multicolumn{3}{|l|}{ Source of information } \\
\hline \multirow[t]{2}{*}{ News } & $480(46.0)$ & "The news is everywhere." \\
\hline & & "...news outlets such as CNN Fox News CBS...." \\
\hline \multirow[t]{2}{*}{ Social media } & $177(17.0)$ & "...Twitter, Reddit, CNN" \\
\hline & & "Heard about it on Instagram first...." \\
\hline \multirow[t]{2}{*}{ Friends and family } & $124(11.9)$ & "...hearing from family and friends." \\
\hline & & $\begin{array}{l}\text { "I know a lot about it as my mom has been } \\
\text { non-stop feeding me information." }\end{array}$ \\
\hline \multirow[t]{2}{*}{ Government or academia } & $89(8.5)$ & $\begin{array}{l}\text { "I read every article from the CDC, the WHO, } \\
\text { and stats.com." }\end{array}$ \\
\hline & & $\begin{array}{l}\text { "I've kept up-to-date on COVID-19 through the } \\
\text { legitimate sources we should be trusting, the } \\
\text { CDC and WHO." }\end{array}$ \\
\hline School & $88(8.4)$ & $\begin{array}{l}\text { "...l heard that from a teacher at school." } \\
\text { "... a lot of school emails" }\end{array}$ \\
\hline
\end{tabular}

CBS = Columbia Broadcasting System; CDC = Centers for Disease Control; CNN = Cable News Network; COVID-19 = coronavirus disease 2019; WHO = World Health Organization.

a Totals may not add to $100 \%$ because codes are not mutually exclusive.

respondents also reported worry, primarily for others, and increased use of prevention measures, such as social distancing.

Contrary to the common perception that adolescents and young adults are disengaged, youth in our study demonstrated high levels of engagement in learning about the pandemic, with many youth turning to news outlets for information. ${ }^{9-11}$ Although most information reported was accurate, some individuals cited inaccurate or non-evidenced-based information. A scientific understanding of COVID-19, from infection risks to impacts on schools, is important as this information influences youths' perceptions and behaviors. Accurate information targeted toward youth is necessary to ensure engagement in appropriate behaviors, particularly given that findings from our study suggest adolescent and young adults are consuming and acting upon this information. Additional consideration should also be given to educating youth on critically assessing and interpreting the sources of online information. ${ }^{32}$ Leveraging youths' interest in understanding the evolving COVID-19 phenomenon may be important in developing efforts to promote healthy behaviors during the pandemic and beyond.

Between the 2 survey dates of our study, every state recorded a COVID-19 case and coronavirus disease 2019 was declared a pandemic, which may explain why nearly all participants reported being impacted by the pandemic by March 20, 2020, with increasing numbers of youth expressing worry or concern. ${ }^{33}$ Notably, youth in our sample primarily expressed concern for others, like family, friends, or individuals at higher risk due to their job, socioeconomic status, or health conditions. This finding is also contrary to a commonly held belief and media portrayal of youth as selfcentered and unempathetic. ${ }^{22-26}$ As public health planning evolves, it is important to acknowledge youths' concern for others as a driver of their behavior and to create programs that are informed by their beliefs and perspectives.

Feelings of invincibility and the lack of perceived impact of COVID-19 on youth populations have been noted as fueling poor compliance with recommended prevention guidelines. ${ }^{2,30,34-36}$ Youth in our sample noted similar concern about their age group not engaging in prevention. However, only 4 days after the White House released guidelines on use of social distancing (March 16, 2020), one-half of all respondents reported practicing social distancing. ${ }^{37}$ This is particularly significant as youth were not primed with specific prevention measures in our open-ended question on what they were doing to prepare. National data note a comparable uptake of social distancing during this time indicating that, like adults, youth were engaged with the evolving pandemic and adapting their behaviors. ${ }^{38,39}$ Our results further note that many respondents who 
Table 3. Shift in Youth Perspectives of COVID-19 Impact, Worry, and Preparation Measures During March 2020

\begin{tabular}{|c|c|c|c|}
\hline Question, Theme ${ }^{a}$ & $\begin{array}{l}\text { March } 6 \\
\text { No.1 }(\%)\end{array}$ & $\begin{array}{l}\text { March } 20 \\
\text { No.2 (\%) }\end{array}$ & Example Quotes \\
\hline \multicolumn{4}{|c|}{ How has the current coronavirus situation impacted you, if at all? $\left(n_{1}=1,009 ; n_{2}=989\right)$} \\
\hline Impact experienced & $626(62.0)$ & $940(95.0)$ & \\
\hline School and work impacts & $109(17.4)$ & $599(63.7)$ & $\begin{array}{l}\text { "I had to leave my university and come home. I also am now unable to go to either } \\
\text { of my jobs so I have no way of making money." }\end{array}$ \\
\hline Self-isolating & $8(1.3)$ & $385(41.0)$ & "I haven't left the house in a week I'm starting to lose track of the days." \\
\hline Cancellations & $37(5.9)$ & $109(11.6)$ & $\begin{array}{l}\text { "...prom's cancelled, tennis season probably won't happen." } \\
\text { "All my plans around my life have been canceled" }\end{array}$ \\
\hline Anxiety or fear & $170(27.2)$ & $98(10.4)$ & $\begin{array}{l}\text { "It has caused anxiety and fear. I don't want to get sick and I especially don't want } \\
\text { my older family members to get it." }\end{array}$ \\
\hline No impact & $383(38.0)$ & $49(5.0)$ & "It really hasn't affected me." \\
\hline
\end{tabular}

Are you worried about coronavirus? Why or why not? $\left(n_{1}=1,005 ; n_{2}=975\right)$

$\begin{array}{lll}\text { Yes } & 251(25.0) & 494(50.7) \\ \text { Somewhat } & 237(23.6) & 247(25.3) \\ \text { No } & 517(51.4) & 234(24.0)\end{array}$

Reasons worried

Fear for others

$129(26.4) \quad 248(33.5)$

Higher-risk individuals

$107(21.9) \quad 156(21.1)$

"Not so much for my own health but for my parents and grandparents."

"Yes of course, I'm worried about my parents, my family would are [sic] health care providers, for homeless individuals, for the elderly population, everyone who could die from this."

$100(20.5)$

$137(18.5)$

Spreading

$52(10.7)$

$20(4.1)$

$22(4.5)$

66 (13.5)

$44(9.0)$

Poor management

\section{Reasons not worried}

Young $\&$ healthy

Practicing prevention

$178(23.6)$

$44(9.1)$

Mild disease

$74(9.8)$

$27(5.6)$
"I'm worried that I'll spread it."

"...with the quick spread of this disease, it's hard not to be worried."

"Yes, because hospitalization, death, and health care cost."

"Yes, its' a pandemic and should be treated as such."

"I think it's impact on the economy will be felt for years to come...."

"...I'm worried about the economic ramifications/being able to afford rent in coming months."

"Yes, because it's affecting my daily life."

"Yes, because it is slowly stopping and shutting down the world around us."

"I am high-risk patient due to asthma...."

"Heck yeah. I don't wanna die."

"...I'm worried it's not being taken seriously by younger people."

"Yes, our president so far is taking the coronavirus as a joke."

"No, because I'm healthy and would be able to fight off a virus easily."

"Nope because it doesn't affect my age group."

"No, I feel like I've taken the necessary precautions."

"No, because I clean, keep my distance, and wash my hands as a normal routine, something everyone should do."

"Statistically more people die from the flu so not necessarily."

"No, it's such a low death rate...."

"No...to me the situation is a sham."

"No, people are freaking out and it does not matter."

Are you doing anything to prepare for coronavirus? If so, what? $\left(n_{1}=1,000 ; n_{2}=942\right)$

\begin{tabular}{|c|c|c|c|}
\hline \multirow[t]{2}{*}{ Social distancing } & $47(4.7)$ & $472(50.1)$ & "...staying away from public events and places." \\
\hline & & & "Yes, we are doing social distancing to protect people who may be vulnerable." \\
\hline \multirow[t]{2}{*}{ Stocking up } & $175(17.5)$ & $364(38.6)$ & $\begin{array}{l}\text { "I am getting all my medications filled and trying to get perishable food just in } \\
\text { case there is a country lockdown." }\end{array}$ \\
\hline & & & "We have food and supplies loaded up for 2 weeks at the home." \\
\hline Increased hygiene & $297(29.7)$ & $165(17.5)$ & $\begin{array}{l}\text { "Washing hands, sanitizing, cleaning my house frequently...." } \\
\text { "...increased hand washing, avoiding touching my face." }\end{array}$ \\
\hline Nothing & $357(35.7)$ & $137(14.5)$ & "I'm not doing anything to prepare." \\
\hline \multirow[t]{2}{*}{ Normal hygiene } & $174(17.4)$ & $69(7.3)$ & "Hand hygiene as per usual." \\
\hline & & & "I'm just taking regular health precautions." \\
\hline
\end{tabular}


indicated a lack of worry or concern about the ongoing pandemic cited their current prevention practices as reducing their fears. Regardless of their reasoning, many youth are participating in prevention of transmission to a larger degree than the media portrays.

The generalizability of these results is limited as the MyVoice cohort is not a nationally representative sample of youth. Identification of themes in coding may also be biased based on reviewer experiences. This impact is mitigated, however, by the use of 2 independent coders with a third reviewer, inclusion of youth experts in the analysis process, and the short nature of text-message-based surveying.

Many youth in our sample are engaged in learning about the ongoing COVID-19 pandemic, with most being knowledgeable about the disease, concerned about its impacts (particularly on others), and taking appropriate preparation measures. Some youth reported inaccurate information, however, which may play a role in future spread. Understanding these behaviors and perceptions of youth in the United States adds to the growing body of knowledge on COVID-19 that may be useful in informing public planning. Our results suggest that sustained public health efforts should focus on maintaining youth engagement, ensuring accuracy of public information, and using youth-centered messaging to promote prevention measures to protect the health and well-being of youth and their friends and family. Given recommendations for youth to continue receiving routine care, ${ }^{40}$ primary care clinicians have an opportunity to more directly address youth questions and correct misinformation on the pandemic that may impact youths' behaviors.

To read or post commentaries in response to this article, go to https://www.AnnFamMed.org/content/19/2/141/tab-e-letters..

Key words: adolescent; COVID-19; pandemics

Submitted June 17, 2020; submitted, revised, August 27, 2020; accepted September 2, 2020.

Funding support: This research was funded by the Michigan Institute for Clinical \& Health Research, the University of Michigan MCubed program, and the University of Michigan Department of Family Medicine. These funders had no role in the design and conduct of the study; collection, management, analysis, and interpretation of the data; preparation, review, or approval of the manuscript; or decision to submit the manuscript for publication.

\section{References}

1. Hu Z, Song C, Xu C, et al. Clinical characteristics of 24 asymptomatic infections with COVID-19 screened among close contacts in Nanjing, China. Sci China Life Sci. 2020;63(5):706-711.

2. CDC COVID-19 Response Team. Coronavirus disease 2019 in children - United States, February 12-April 2, 2020. MMWR Morb Mortal W/kly Rep. 2020;69(14):422-426.

3. Johns Hopkins Univerity, HUB. The impact of the COVID-19 pandemic on adolescents. Published May 11, 2020. Accessed Jun 9, 2020. https://hub.jhu.edu/2020/05/11/covid-19-and-adolescents/
4. Pew Research Center. Most Americans say coronavirus outbreak has impacted their lives. Published Mar 30, 2020. Accessed Jun 9, 2020. https://www.pewsocialtrends.org/2020/03/30/ most-americans-say-coronavirus-outbreak-has-impacted-their-lives/

5. Pew Research Center. Young workers likely to be hard hit as COVID-19 strikes a blow to restaurants and other service sector jobs. Published Mar 27, 2020. Accessed Jun 9, 2020. https://www.pewresearch.org/ fact-tank/2020/03/27/young-workers-likely-to-be-hard-hit-as-covid19-strikes-a-blow-to-restaurants-and-other-service-sector-jobs/

6. Huang P, NPR news. What we know about the silent spreaders of COID-19. Published Apr 13, 2020. Accessed Jun 9, 2020. https:// www.npr.org/sections/goatsandsoda/2020/04/13/831883560/ can-a-coronavirus-patient-who-isnt-showing-symptoms-infect-others

7. Lin R-G. Coronavirus 'silent spreaders' become a bigger risk as California reopens. Los Angeles Times. May 13, 2020. Accessed Jun 9, 2020. https://www.latimes.com/california/story/2020-05-26/ coronavirus-silent-spreaders-bigger-risk-as-california-reopens

8. Central Intelligence Agency. The world factbook; age structure. Accessed Jun 9, 2020. https://www.cia.gov/library/publications/theworld-factbook/fields/341.html

9. Stauffer R. Young people aren't turning out to vote-but it's not because they don't care. InStyle. Mar 5, 2020. Accessed Jun 9, 2020. https://www.instyle.com/lifestyle/youth-voter-turnout-votersuppression

10. Syvertsen AK, Wray-Lake L, Flanagan CA, Osgood DW, Briddell L. Thirty year trends in U.S. adolescents' civic engagement: a story of changing participation and educational differences. J Res Adolesc. 2011;21(3):586-594.

11. Delli Carpini MX. Gen.com: youth, civic engagement, and the new information environment. Polit Commun. 2000;17(4):341-349.

12. Saad L. Both parties' voters are keyed up for midterm elections. Gallup. Published Sep 27, 2018. Accessed Aug 25, 2020. https://news. gallup.com/poll/243173/parties-voters-keyed-midterm-elections.aspx

13. Sarkar P. How realistic is media portrayal of the youth? shethepeople. Published Nov 1, 2019. Accessed Aug 25, 2020. https://www. shethepeople.tv/blog/how-realistic-is-media-portrayal-of-the-youth/

14. Witt E. From Parkland to Sunrise: a year of extraordinary youth activism. NewYorker.com. Published Feb 13, 2019. Accessed Jun 9, 2020. https://www.newyorker.com/news/news-desk/ from-parkland-to-sunrise-a-year-of-extraordinary-youth-activism

15. Nasheed J. Youth activitist movements of the 2010s: a timeline and brief history of a decade of change. teenvogue. Published Dec 16, 2019. Accessed Aug 25, 2020. https://www.teenvogue.com/story/ youth-activist-movements-2010s-brief-history-timeline-decade-ofchange

16. Eichen A. Why aren't young people more involved in politics? yes! magazine. Published Oct 10, 2018. Accessed Aug 25, 2020. https:// www.yesmagazine.org/opinion/2018/10/10/why-arent-youngpeople-more-involved-in-politics/

17. Wells M. Media casts youth in a constant bad light. The Guardian. Oct 12, 2004. Accessed Jun 9, 2020. https://www.theguardian.com/ media/2004/oct/12/pressandpublishing.broadcasting

18. Kelly C. Three ways teenagers are misrepresented in society. The Conversation. Published Aug 29. 2018. Accessed Jun 9, 2020. https://theconversation.com/three-ways-teenagers-aremisrepresented-in-society-101557

19. Cammaerts B, Bruter M, Banaji S, Harrison S, Anstead N. The myth of youth apathy: young Europeans' critical attitudes toward democratic life. Am Behav Sci. 2013;58(5):645-664.

20. Galván A. The teenage brain: sensitivity to rewards. Curr Dir Psychol Sci. 2013;22(2):88-93.

21. Telzer EH, Fuligni AJ, Lieberman MD, Galván A. Neural sensitivity to eudaimonic and hedonic rewards differentially predict adolescent depressive symptoms over time. Proc Natl Acad Sci U S A. 2014; 111(18):6600-6605. 
22. Konrath SH, O'Brien EH, Hsing C. Changes in dispositional empathy in American college students over time: a meta-analysis. Pers Soc Psychol Rev. 2011;15(2):180-198.

23. Van der Graaff J, Branje S, De Wied M, Hawk S, Van Lier P, Meeus W. Perspective taking and empathic concern in adolescence: gender differences in developmental changes. Dev Psychol. 2014;50(3): 881-888.

24. Time. Millennials: The me me me generation. Published May 20, 2013. Accessed Jun 9, 2020. http://content.time.com/time/subscriber/article/0,33009,2143001,00.html

25. Chokshi N. Attention young people: this narcissism study is all about you. The New York Times. May 15, 2019. Accessed Jun 9 2020. https://www.nytimes.com/2019/05/15/science/narcissismteenagers.html

26. Grubbs JB, Exline JJ, McCain J, Campbell WK, Twenge JM. Emerging adult reactions to labeling regarding age-group differences in narcissism and entitlement. PLoS One. 2019;14(5):e0215637

27. National Academies of Sciences, Engineering, and Medicine. The promise of adolescence: realizing opportunity for all youth. Published 2019. Accessed Jun 9, 2020. https://www.nap.edu/ catalog/25388/the-promise-of-adolescence-realizing-opportunityfor-all-youth

28. Preidt R. Why teens find it tough to social distance. U.S.News. Published Apr 5, 2020. Accessed Jun 9, 2020. https://www.usnews.com/ news/health-news/articles/2020-04-05/why-teens-find-it-tough-tosocial-distance

29. Vidrascu E. Social distancing "isn't working" for some young people - why not? Direct JPHMP. Published Mar 25, 2020. Accessed Jun 9, 2020. https://jphmpdirect.com/2020/03/25/ social-distancing-isnt-working-for-some-young-people-why-not/

30. Gordon S. Why are teens, millennials ignoring coronavirus warnings? U.S. News. Published Mar 26, 2020. Accessed Jun 9, 2020. https://www.usnews.com/news/health-news/articles/2020-03-26/ why-are-teens-millennials-ignoring-coronavirus-warnings

31. Dejonckheere $M$, Nichols LP, Moniz MH, et al. MyVoice national text message survey of youth aged 14 to 24 years: study protocol. JMIR Res Protoc. 2017;6(12):e247.
32. The Conversation. How to spot coronavirus fake news - an expert guide. Published Mar 20, 2020. Accessed Jun 9, 2020. https:// theconversation.com/how-to-spot-coronavirus-fake-news-an-expertguide- 133843

33. Muccari R, Chow D, Murphy J. Coronavirus timeline: tracking the critical moments of COVID-19. NBC News. Published Mar 10, 2020. Accessed Jun 9, 2020. https://www.nbcnews.com/health/healthnews/coronavirus-timeline-tracking-critical-moments-covid-19n1154341

34. Wickman ME, Anderson NL, Greenberg CS. The adolescent perception of invincibility and its influence on teen acceptance of health promotion strategies. J Pediatr Nurs. 2008;23(6):460-468.

35. Gringlas S. 'They're feeling invincible': White House steps up warnings to young adults. NPR Special Series: The Coronavirus Crisis. Published Mar 19, 2020. Accessed Jun 9, 2020. https://www.npr. org/2020/03/19/817969931/they-re-feeling-invincible-white-housesteps-up-warnings-to-young-adults

36. Nebehay S. WHO message to youth on coronavirus: 'You are not invincible'. Reuters. Published Mar 20, 2020. Accessed Jun 9, 2020. https://www.reuters.com/article/us-health-coronavirus-who/ who-message-to-youth-on-coronavirus-you-are-not-invincible-idusKBN217330

37. Harris R. White House announces new social distancing guidelines around coronavirus. NPR. Published Mar 16, 2020. Accessed Jun 9, 2020. https://www.npr.org/2020/03/16/816658125/white-houseannounces-new-social-distancing-guidelines-around-coronavirus

38. Canipe C. The social distancing of America. Reuters. Published Apr 2, 2020. Accessed Aug 25, 2020. https://graphics.reuters.com/ HEALTH-CORONAVIRUS/USA/qmypmkmwpra/

39. Saad L. Americans step up their social distancing even further. Gallup blog. Published Mar 24, 2020. Accessed Aug 25, 2020. https:// news.gallup.com/opinion/gallup/298310/americans-step-socialdistancing-even-further.aspx

40. American Academy of Pediatrics. Guidance on providing pediatric well-care during COVID-19. Accessed Aug 25, 2020. https://services. aap.org/en/pages/2019-novel-coronavirus-covid-19-infections/clinicalguidance/guidance-on-providing-pediatric-well-care-during-covid-19/ 